\title{
Deteksi Limfosit Plasma Biru pada Citra Darah untuk Diagnosa Pendukung pada Kasus Demam Berdarah Dengue
}

\author{
SUCI AULIA, SUGONDO HADIYOSO
}

Fakultas IImu Terapan, Universitas Telkom, Bandung, Indonesia

Email: suciaulia@telkomuniversity.ac.id

Received 20 September 2020 | Revised 2 Oktober 2020 | Accepted 20 Oktober 2020

\begin{abstract}
ABSTRAK
Demam Berdarah Dengue (DBD) adalah salah satu penyakit mematikan yang disebabkan oleh virus dengue sehingga diagnosis dini DBD sangat penting dilakukan. Secara umum, diagnosis dini DBD dilakukan melalui pemeriksaan trombosit namun pemeriksaan ini tidak spesifik. Salah satu uji klinis lainnya yang dapat dilakukan untuk diagnosis dini DBD adalah deteksi limfosit plasma biru (LPB) melalui pencitraan sel darah. Oleh karena itu, pada studi ini diusulkan metode deteksi LBP secara otomatis pada citra mikroskopis darah. Data dikumpulkan dari pasien dengue dan subjek normal. Pada studi ini digunakan 20 gambar dataset yang terdiri dari 10 gambar terinfeksi dengue dan 10 gambar limfosit biasa sebagai kondisi normal. Ekstraksi ciri dilakukan dengan filter Gabor dan kemudian validasi dilakukan dengan K-Nearest Neigbor (K-NN) dan 5-fold cross validation. Dari pengujian yang dilakukan diperoleh akurasi deteksi tertinggi sebesar $90 \%$, dimana dicapai menggunakan metode Cosine K-NN. Hasil studi ini diharapkan dapat digunakan dalam menunjang penegakan diagnosa penyakit dengue.
\end{abstract}

Kata kunci: demam berdarah dengue, deteksi, limfosit, $K-N N$

\begin{abstract}
Dengue Hemorrhagic Fever (DHF) is a deadly disease caused by the dengue virus, so early diagnosis of DHF is very important. Commonly, early diagnosis of dengue fever is done through a platelet examination, but this examination is not specific. One of the other clinical tests that can be done for early diagnosis of DHF is detection of blue plasma lymphocytes (LBP) through blood cell imaging. Therefore, this study proposes an automatic $\angle B P$ detection method on microscopic blood images. Data were collected from dengue patients and normal subjects. A total of 20 images were analyzed in this study consisting of 10 images infected with dengue and 10 images of normal lymphocytes as normal conditions. Feature extraction was carried out with the Gabor filter and then the validation was carried out with $K$-Nearest Neigbor (K-NN) and 5-fold cross validation. From the tests conducted, the highest detection accuracy is $90 \%$, which is achieved using the Cosine $K-N N$ method. The results of this study are expected to be used in supporting the diagnosis of dengue disease.
\end{abstract}

Keywords: Dengue hemorrhagic fever, detection, lymphocytes, K-NN 
Deteksi Limfosit Plasma Biru pada Citra Darah untuk Diagnosa Pendukung pada Kasus Demam

Berdarah Dengue

\section{PENDAHULUAN}

Demam berdarah dengue atau kemudian disingkat DBD adalah penyakit yang disebabkan oleh salah satu dari empat virus dengue dengan serotipe berbeda (DEN-1, DEN-2, DEN-3, dan DEN4) dari famili Flaviviridae (Hasan, dkk, 2016) (Kurane, 2007). Penyakit ini ditularkan di dalam tubuh manusia melalui nyamuk Aedes aegypti (Metrikawati, 2014) (Sorisi, 2013). Demam berdarah merupakan penyakit yang mudah menular yang sangat endemik di negaranegara tropis (Khetarpal \& Khanna, 2016). Gejala yang dialami oleh pasien umumnya muncul 4-7 hari sejak gigitan nyamuk, dan dapat berlangsung selama 10 hari. Pasien dapat mengalami demam tinggi, sakit kepala, nyeri pada sendi/tulang, mual dan muntah, ruam kemerahan, dan beberapa mengalami perdarahan dari hidung, gusi, atau di bawah kulit (Hasan, dkk, 2016). Pada masa demam jumlah trombosit dapat menurun drastis sehingga menyebabkan pendarahan. Di Indonesia, penyakit DBD menjadi salah satu penyebab kematian tertinggi. World Health Organization (WHO) mencatat negara Indonesia sebagai negara dengan kasus DBD tertinggi di Asia Tenggara terhitung sejak tahun 1968 hingga tahun 2009 (Kemenkes RI, 2010).

Infeksi virus dengue dapat muncul dengan gambaran klinis yang beragam seperti yang disebutkan di atas dan beberapa lainnya asimtomatik atau tanpa gejala (Aryu, 2010). Diagnosis dini dan akurat sangat penting untuk mengurangi kematian terlebih terapi antivirus saat ini tidak tersedia (Hasan, dkk, 2016). Namun demikian, diagnosis DBD yang akurat sulit dilakukan dan bergantung pada konfirmasi laboratorium. Saat ini penegakan atau diagnosis DBD dilakukan dengan melakukan pemeriksaan fisik, wawancara medis dan pemeriksaan penunjang, seperti pemeriksaan sel darah. Berdasarkan protokol WHO, pemeriksaan trombosit merupakan salah satu kriteria laboratorium yang digunakan dalam penegakkan diagnosis, namun ini non spesifik. Pemeriksaan klinis penunjang lainnya adalah dengan uji antibodi IgM dan IgG (Indrawan, dkk, 2018). Dengan demikian untuk mendapatkan diagnosa akurat sampai saat ini masih menjadi tantangan yang terus dikembangkan. Salah satu kriteria penunjang klinis lainnya adalah deteksi Limfosit Plasma Biru (LPB) melalui pencitraan sel darah (Irianti, dkk, 2016). Metode ini banyak digunakan karena cepat dan murah.

Beberapa studi menitikberatkan deteksi LBP untuk diagnosa DBD berdasarkan citra sel darah. Penelitian oleh Mustakimah, menunjukkan bahwa pasien yang positif ditemukan LPB $\geq 4 \%$ berdasarkan derajat DHF sebanyak 97\% pada preparat darah tepi (Mustakimah, 2012). Arruan dkk, melaporkan bahwa LBP dijumpai pada pasien DBD (Arruan, dkk, 2015). Namun deteksi dan perhitungan LBP dilakukan secara manual, diperlukan ketelitian dan pengalaman tenaga medis. Studi lainnya oleh Raharjo dan Hadi, melakukan deteksi dan perhitungan jumlah limfosit secara otomatis menggunakan Sysmex XN-1000 hematology analyzer (Raharjo \& Hadi, 2019). Namun demikian, ini menjadikan ketergantungan terhadap perangkat lunak dari produsen alat tersebut. Studi serupa oleh Clarice dkk, menggunakan Sysmex XS500i untuk mengorelasikan jumlah limfosit terhadap derajat keparahan infeksi dengue (Clarice, dkk, 2019). Analisis limfosit pada pasien terinfeksi dengue juga dilaporkan pada studi Prabhavathi dkk. (Prabhavathi, dkk, 2017), dimana proses deteksi juga menggunakan hematology analyzer. Penelitian-penelitian tersebut menunjukkan bahwa LBP menggambarkan kondisi patologi pada pasien yang terinfeksi dengue dan membuktikan bahwa analisis LBP dapat digunakan untuk diagnosis penyakit ini. Namun dari penelitian tersebut, beberapa dari mereka melakukan deteksi dan perhitungan secara manual dan beberapa lainnya menggunakan aplikasi hematology analyzer. Oleh karena itu pada usulan studi ini, dikembangkan sebuah metode deteksi LBP secara otomatis berdasarkan citra sel darah. 
Pada studi ini, gambaran sel darah diambil dari pasien DBD dan subjek normal yang diletakkan pada preparat untuk dilakukan perbesaran menggunakan mikroskop digital. Data gambar dikumpulkan dari RS Al Islam, Bandung dengan jumlah total dataset adalah 20, terdiri dari 10 gambar dari pasien dengue dan 10 gambar dari subjek normal. Dari gambar sel darah tersebut kemudian dilakukan segmentasi dan deteksi LBP untuk menentukan kondisi terinfeksi atau tidak terinfeksi dengue. Pada studi ini, ekstraksi ciri menggunakan filter Gabor. Uji validasi performa usulan metode dilakukan menggunakan K-Nearest Neighbor (K-NN) dan 5-fold cross validation. Beberapa model K-NN diterapkan untuk menguji kekokohan metode yang diusulkan.

\section{METODOLOGI PENELITIAN}

Hasil keluaran dari sistem ini akan mengklasifikasikan kondisi sampel darah menjadi dua kondisi yaitu normal dan terinfeksi dengue seperti yang ditunjukkan alurnya pada Gambar 1.

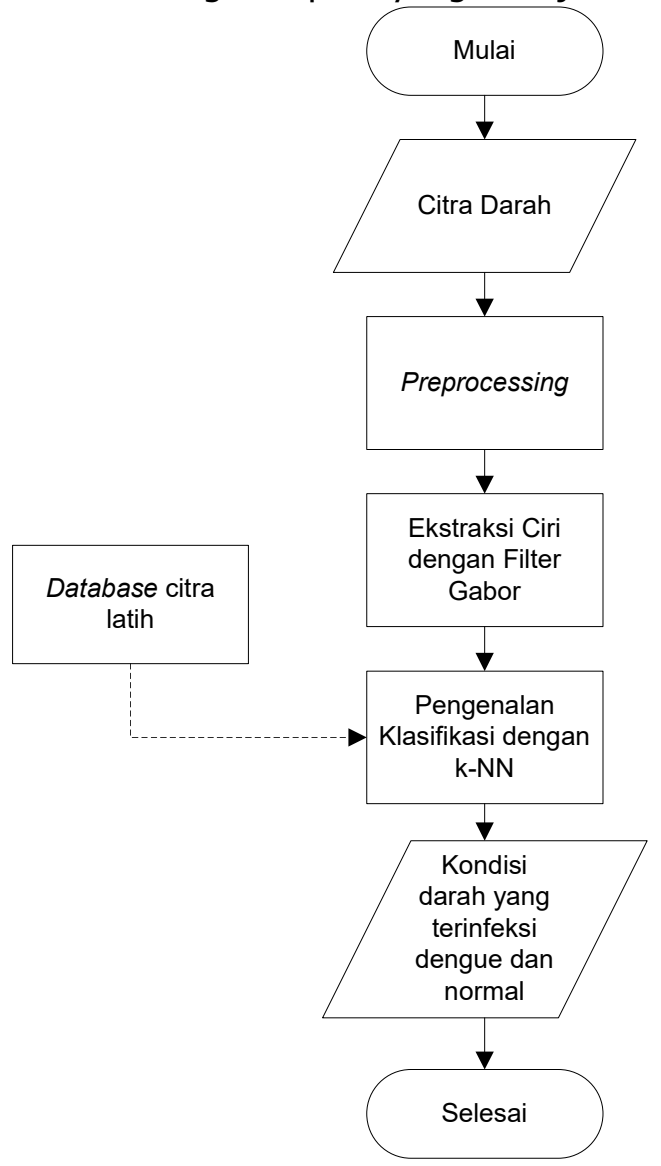

Gambar 1. Diagram Alur Sistem

Pengambilan citra darah dilakukan menggunakan kamera ponsel, dimana citra yang dipotret tersebut diambil dengan bantuan mikroskop, di laboraturium RS. Al Islam Bandung. Dalam hal ini citra yang diperoleh dalam format $*$ JPEG, dengan ukuran bervariasi, namun ukuran dominan yang diperoleh yaitu 3264 × 2448 piksel.

\subsection{Preprocessing}

Preprocessing merupakan sebuah proses awal yang dilakukan pada suatu citra digital sebelum dilakukan pemrosesan citra selanjutnya. Dari tahapan pre-processing citra ini diharapkan dapat menghasilkan citra dengan kandungan noise seminimal mungkin. Tahapan 
preprocessing pada penelitian ini adalah tahap-1 resize citra dataset dari 3264 × 2448 piksel menjadi 700 x 550 piksel. Tahap 2 dilakukan image enhancement pada citra hasil resize dengan histogram equalisasi. Tahap 3 adalah konversi warna dari RGB ke grayscale. Tahap-4 adalah thresholding untuk melakukan segmentasi antara sel darah dengan objek. Tahap-5 merupakan tahap terakhir yaitu proses erosi dan dilasi untuk memperjelas bentuk objek plasma.

\subsection{Filter Gabor}

Filter Gabor merupakan filter yang bekerja berbasis wavelet. Fungsi Gabor dapat bekerja optimal baik dalam domain spasial maupun domain frekuensi. Secara spasial, fungsi Gabor merupakan sinusoida yang dimodulasi oleh fungsi Gaussian. Persamaan filter Gabor 2D adalah sebagai berikut (Kusban, 2015)(Wang, dkk, 2012) :

dimana :

$$
h(x, y)=\frac{1}{2 \pi} \exp \left[-a^{2 j} \frac{x^{2}+y^{2}}{2}\right] \exp \left[j \pi a^{j}(x \cos \theta+y \sin \theta)\right]
$$

$$
\mathrm{a}=\frac{1}{\sqrt{2}}, \mathrm{j}=0,1,2 \ldots \text { dan } \theta_{\epsilon}[0,2 \pi]
$$

Pemilihan frekuensi $\mathrm{j}$ dan orientasi $\theta$ yang berbeda-beda akan membentuk sebuah filter. Vektor ciri dihasilkan dari keluaran filter dengan kombinasi nilai frekuensi $\mathrm{j}$ dan nilai orientasi $\theta$ sehingga menghasilkan sejumlah ciri (feature) dari sebuah tekstur. Hubungan jumah j dan $\theta$ yang digunakan berbanding lurus dengan jumlah ciri yang dihasilkan. Keluaran filter merupakan modulasi dari rata-rata konvolusi mask filter riil dan imajiner terhadap citra karakter seperti yang ditunjukkan pada Persamaan 2.

$$
\text { Output }=\sqrt{R^{2} \text { ave }+I^{2} \text { ave }}
$$

Dimana $R_{a v e}$ merupakan hasil konvolusi dari citra karakter dengan filter mask riil sedangkan $\mathrm{I}_{\text {ave }}$ merupakan hasil konvolusi dari citra karakter dengan filter mask imajiner.

\subsection{K-Nearest Neighbor(KNN)}

Nearest neighbor merupakan suatu teknik nonparametric sederhana dan sangat efisien yang biasa digunakan diberbagai bidang seperti pengenalan pola dan klasifikasi untuk data besar (Naik \& Koley, 2019). Salah satu algoritma yang paling banyak digunakan dalam aplikasi machine learning adalah k-NN. Algoritma ini bekerja dengan menggunakan vektor input dengan k-terdekat pada sampel pelatihan. Untuk melakukan klasifikasi, algoritma mengidentifikasi kelas yang paling banyak muncul di antara k tetangga terdekat. KNN memiliki enam jenis classifier yaitu sebagai berikut (Vitola, dkk, 2017)(Johnson \& Yadav, 2018):

a. Fine KNN : suatu NN classifier bekerja dengan membuat finely-detailed antara perbedaan kelas dengan jumlah set ketetanggaan adalah 1.

b. Medium KNN : suatu NN classifier yang membuat perbedaan yang lebih sedikit dari Fine KNN dengan jumlah set ketetanggaan mencapai 10.

c. Coarse KNN :suatu NN classifier yang membuat perbedaan antar kelas dengan jumlah set ketetanggaan mencapai 100.

d. Cosine KNN : suatu NN classifier yang menggunakan cosine distance metric. Jarak cosine antara dua vektor $u$ dan $v$ ditunjukkan dengan persamaan berikut :

$$
\text { cosine distance metric }=1-\frac{u . v}{|u| \cdot|v|^{\prime}}
$$

e. Cubic KNN : suatu NN classifier yang menggunakan cubic distance metric. Jarak cubic antara $n$ - dimensional vektor $u$ dan $v$ ditunjukkan pada persamaan berikut : 


$$
\text { cubic distance metric }=\sqrt[3]{\sum_{i=1}^{n}\left|u_{i}-v_{i}\right|^{3}}
$$

f. Wighted KNN : suatu NN classifier yang menggunakan weighting. Jarak euclidean weighted antara $2 n$ - dimensional vektor $u$ dan $v$ ditunjukkan pada persamaan berikut (Ibrahim, dkk, 2018) (Kartika \& Santoso, 2017)(Krisandi \& Prihandono, 2013)(Geler, dkk, 2016)(Sooai, dkk, 2018):

$$
\text { euclidean weighted }=\sqrt{\sum_{i=1}^{n} w_{i}\left(x_{i}-y_{i}\right)^{2}}
$$

\section{HASIL DAN PEMBAHASAN}

Pada studi ini, tiga percobaan klasifikasi berdasarkan jumlah ciri $(8,16$, dan 24) pada setiap data telah diujikan. Data merupakan citra fundus yang berasal dari RS Al Islam Bandung dengan jumlah total dataset adalah 20, dari 20 data tersebut terdiri dari 10 data dengue dan 10 data normal. Pada setiap kelas (dengue dan non dengue), data dikelompokkan menjadi training dataset dan testing dataset. Citra dataset berformat .jpg berukuran 3264 x 2448 piksel seperti yang ditunjukkan pada Gambar 2.

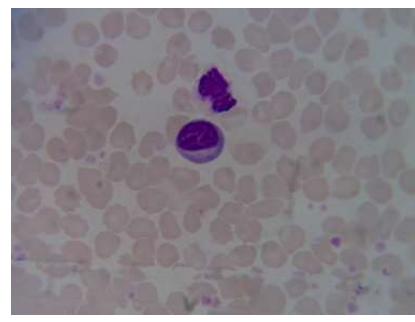

(a)

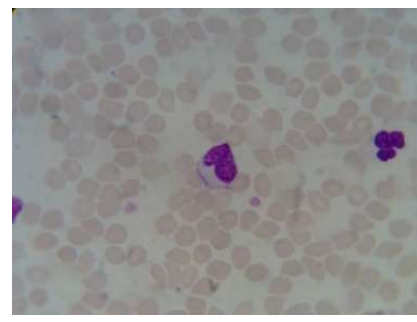

(b)

\section{Gambar 2. Citra Sampel Mikroskopis dari (a). Citra Terinfeksi Dengue, (b) Citra Normal Limfosit Biasa}

\subsection{Ekstraksi Ciri dengan Filter Gabor}

Ekstraksi ciri terhadap sampel dataset pada penelitian ini dilakukan dengan variasi 8 ciri, 16 ciri, dan 24 ciri menggunakan filter Gabor. Parameter filter Gabor pada masing-masing ciri menggunakan variasi frekuensi yang sama $(2 \mathrm{~Hz}, 3 \mathrm{~Hz}$ dan $4 \mathrm{~Hz}$ ) dan variasi orientasi yang sama $(0,25 \pi ; 1,25 \pi$; dan $\pi)$. Nilai ciri yang dihasilkan tergantung pada nilai frekuensi yang dikalikan dengan nilai orientasi. Nilai-nilai tersebut menghasilkan kernel riil dan kernel imajiner, selanjutnya kedua kernel tersebut dikonvolusikan dengan citra dataset sampel sel darah. Tabel 1 menunjukkan nilai rata-rata vektor ciri untuk citra normal lebih tinggi dari citra terinfeksi dengue. Nilai vektor ciri hasil feature extraction dengan filter Gabor selanjutnya dijadikan database untuk diklasifikasi dengan algoritma K-Nearest Neighbor. 
Tabel 1. Nilai Rata-Rata Vector Ciri Citra Normal dan Citra Dengue.

\begin{tabular}{|c|c|c|}
\hline \multirow{2}{*}{ Jumlah Ciri } & \multicolumn{2}{|c|}{ Vektor ciri } \\
\cline { 2 - 3 } & Normal & Terinfeksi Dengue \\
\hline 8 ciri & 0,02518116 & 0,002416349 \\
\hline 16 ciri & 0,01580431 & 0,003942384 \\
\hline 24 ciri & 0,02051501 & 0,004804286 \\
\hline
\end{tabular}

Berdasarkan Tabel 1, nilai rata-rata magnitude vektor ciri citra normal lebih tinggi dibandingkan citra terinfeksi dengue yaitu 0,02050016 berbanding 0,003721006. Gap antara kedua nilai rata-rata vektor ciri tersebut berkisar $10^{-1}$, sehingga hal ini memungkinkan sistem dapat memiliki tingkat akurasi yang tinggi pada proses pengujian klasifikasi.

\subsection{Klasifikasi dengan KNN}

Proses klasifikasi diujicobakan dengan 6 jenis algoritma classifier pada metode KNN, yaitu: Fine KNN, Medium KNN, Coarse KNN, Cubic KNN dan Weighted KNN. Setiap algoritma classifier tersebut menggunakan Euclidean distance untuk menentukan jarak ketetanggaannya. Parameter yang digunakan pada klasifikasi adalah Cross validation; 5 folds, Jumlah neighboors; $\mathrm{k}=100$, Distance Metric, Euclidean, Distance weight, Equal, PCA; $90 \%$ variansi. Hasil pengujian untuk masing-masing ciri disajikan pada Tabel 2.

Tabel 2. Klasifikasi Dengue dengan 8,16, dan 24 Ciri.

\begin{tabular}{|l|l|c|c|c|}
\hline \multirow{2}{*}{ No } & \multirow{2}{*}{ KNN Classifier } & \multicolumn{3}{|c|}{ Tingkat Akurasi } \\
\cline { 3 - 5 } & & $\mathbf{8}$ ciri & $\mathbf{1 6}$ ciri & $\mathbf{2 4}$ ciri \\
\hline 1 & Fine KNN & $85 \%$ & $85.7 \%$ & $19 \%$ \\
\hline 2 & Medium KNN & $85 \%$ & $76.2 \%$ & $47.6 \%$ \\
\hline 3 & Coarse KNN & $50 \%$ & $47.6 \%$ & $47.6 \%$ \\
\hline 4 & Cosine KNN & $90 \%$ & $61.9 \%$ & $47.6 \%$ \\
\hline 5 & Cubic KNN & $85 \%$ & $76.2 \%$ & $47.6 \%$ \\
\hline 6 & Weighted KNN & $85 \%$ & $85.7 \%$ & $9.5 \%$ \\
\hline \multicolumn{2}{|l|}{ Rata-rata } & $80 \%$ & $72.2 \%$ & $36.5 \%$ \\
\hline \multicolumn{2}{|l}{ Waktu Proses } & 0.65 detik & 1.2 detik & 1.7 detik \\
\hline
\end{tabular}

Tabel 2 menunjukkan proses klasifikasi pada 8 ciri dengan Cosine classifier memiliki tingkat akurasi tertinggi di antara 5 classifier lainnya yaitu $90 \%$. Proses klasifikasi pada 16 ciri mendapat tingkat akurasi tertinggi $85.7 \%$ dengan Fine KNN dan Weighted KNN classifier. Sedangkan proses klasifikasi dengan 24 ciri memperoleh nilai rata-rata akurasi terkecil dari ke6 classifier yaitu $36.5 \%$. Secara visual dapat dilihat pada Gambar 3, nilai akurasi tertinggi klasifikasi penyakit DBD berdasarkan citra fundus untuk 20 data adalah $90 \%$ dengan Cosine KNN classifier. 


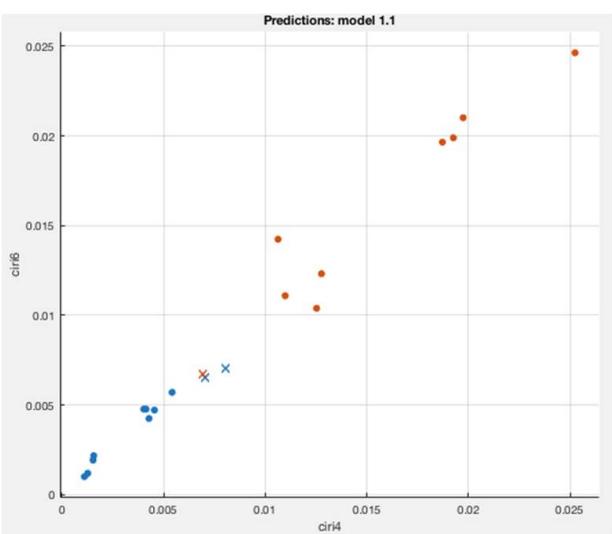

(a)

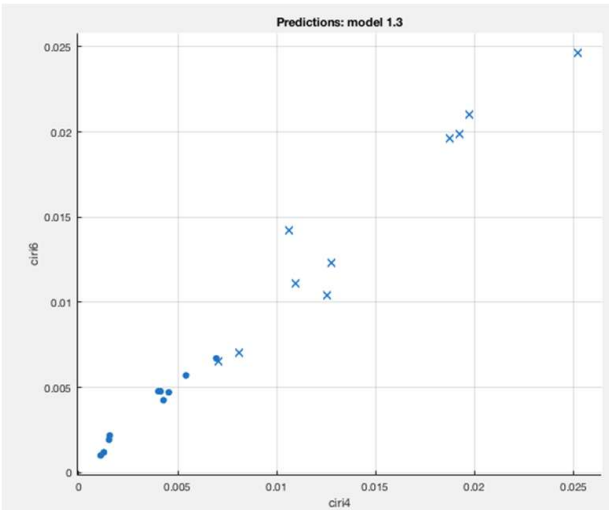

(c)

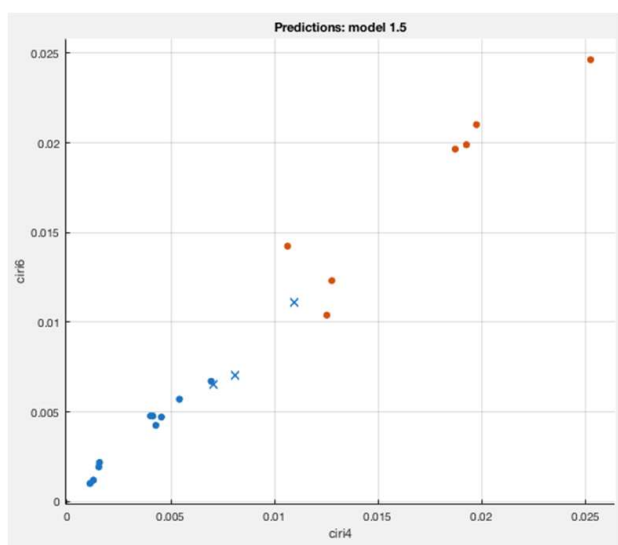

(e)

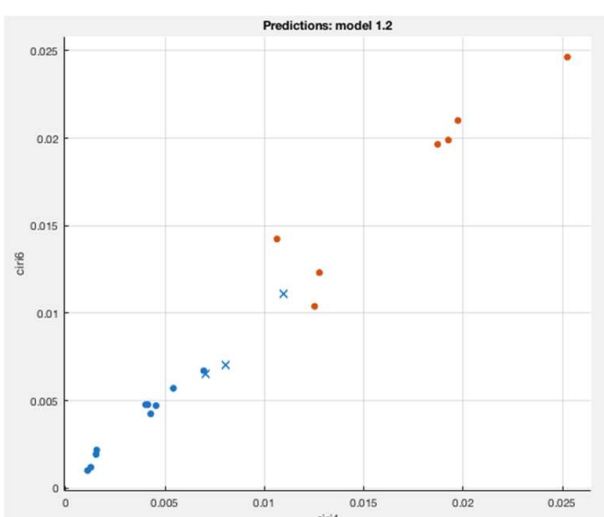

(b)

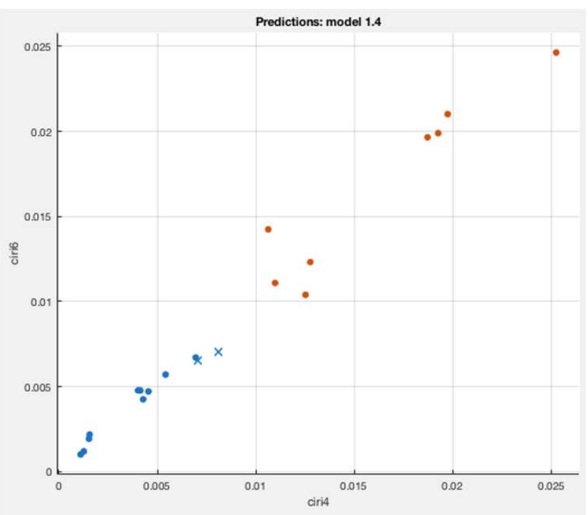

(d)

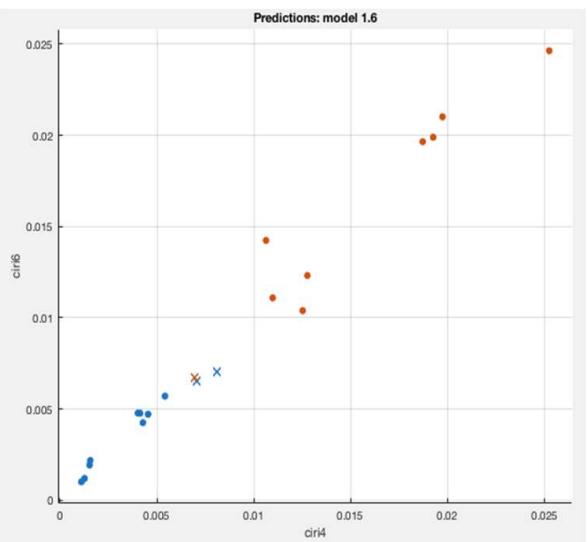

(f)

\section{Gambar 3. Scatter Plot Klasifikasi DBD pada; a) Fine KNN, b) Medium KNN, c) Coarse} KNN, d) Cosine KNN, e) Cubic KNN, dan f) Weighted KNN.

Gambar 3 merupakan grafik scatter plot hasil klasifikasi untuk setiap 6 jenis classifieri KNN. Dot merah menunjukkan data dengue, dot biru menunjukkan data nondengue. Sedangkan data cross menunjukkan data tersebut terklasifikasi sebagai keduanya yaitu dengue dan nondengue sehingga proses klasifikasi tidak teridentifikasi (gagal) pada data tersebut. Secara keseluruhan, dengan jenis grafik parallel coordinates plotperbandingan hasil klasifikasi dengan 8 ciri, 16 ciri, dan 24 ciri dapat dilihat pada Gambar 4, Gambar 5, dan Gambar 6. 
Deteksi Limfosit Plasma Biru pada Citra Darah untuk Diagnosa Pendukung pada Kasus Demam Berdarah Dengue

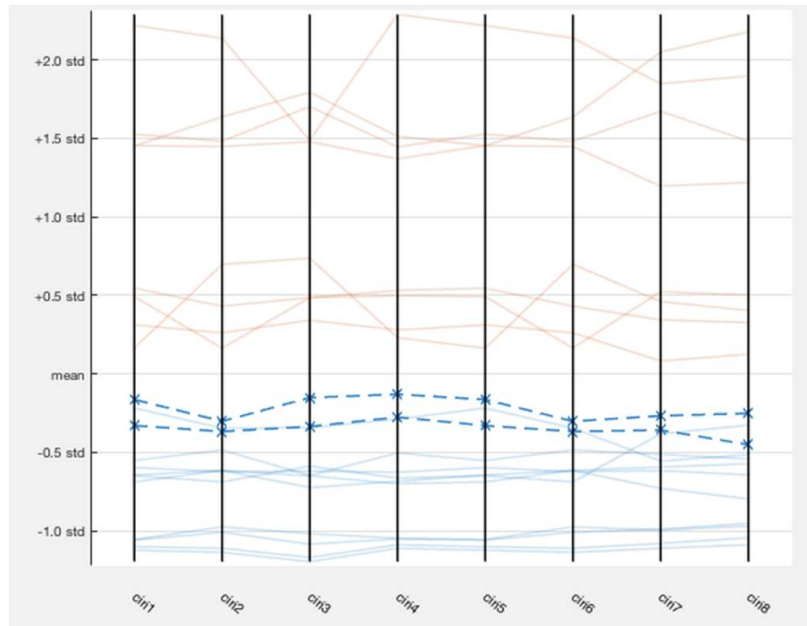

Gambar 4. Grafik Parallel Coordinates Plot Perbandingan Hasil Klasifikasi dengan 8 Ciri.

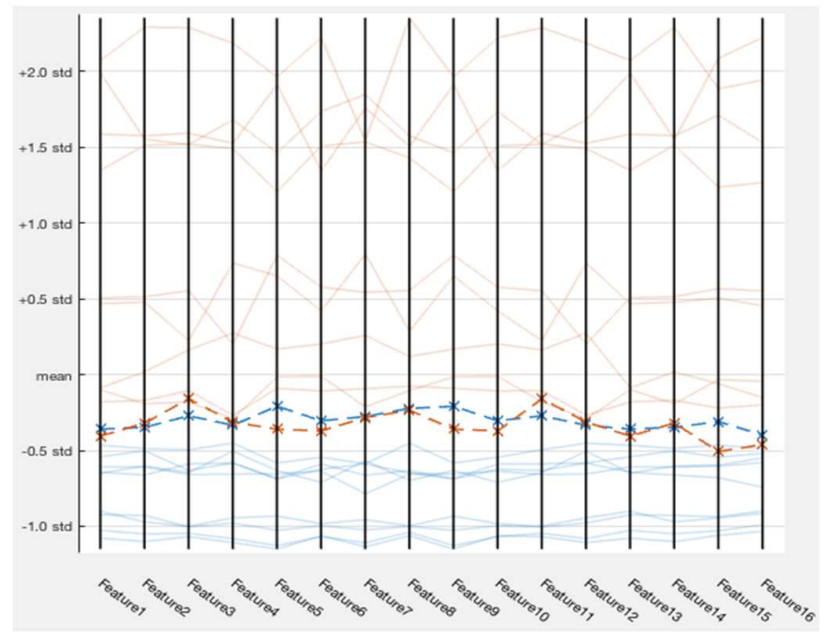

Gambar 5. Grafik Parallel Coordinates Plot Perbandingan Hasil Klasifikasi dengan 16 Ciri

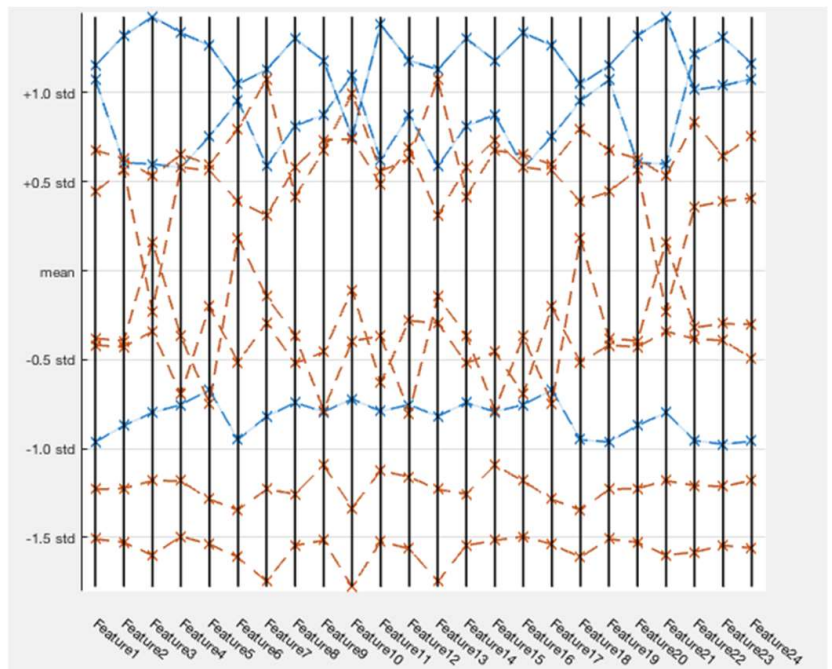

Gambar 6. Grafik Parallel Coordinates Plot Perbandingan Hasil Klasifikasi dengan 24 Ciri 
Gambar 4 menunjukkan perbandingan nilai 8 ciri antara citra darah normal dan citra darah dengan dengue. Secara visual, keduanya menunjukkan perbedaan dengan batas pemisah yang jelas. Ini mengonfirmasi hasil akurasi tertinggi sebesar $90 \%$ dicapai dengan 8 ciri. Sementara itu pada perbandingan nilai 16 dan 24 ciri seperti yang ditunjukkan pada Gambar 5 dan 6, terlihat nilai ciri yang saling bersinggungan antara dua kelompok citra. Hal ini dapat menyebabkan penurunan kinerja K-NN sehingga akurasi deteksi menjadi rendah. Dengan memperhatikan karakteristik tersebut, maka metode yang diusulkan ini dapat bekerja optimal dengan menggunakan 8 nilai ciri hasil filter Gabor.

\section{KESIMPULAN}

Studi ini telah berhasil menyimulasikan sebuah metode deteksi limfosit plasma biru (LBP) pada citra mikoskopis darah untuk mendukung diagnosa demam berdarah dengue. Citra darah diambil di laboraturium RS. Al Islam Bandung menggunakan kamera ponsel dan mikroskop. Citra darah yang diobservasi berukuran 3264 × 2448 piksel dengan format .*JPEG. Ekstraksi ciri terhadap sampel dataset tersebut dilakukan menggunakan filter Gabor. Jumlah ciri yang dihitung dilakukan dengan beberapa skenario termasuk 8, 16 dan 24 ciri. Dari seluruh skenario tersebut menunjukkan perbedaan ciri antara citra darah normal dan citra darah yang terinfeksi virus dengue. Nilai vektor ciri sampel normal lebih besar dibandingkan dengan vektor ciri pada sampel darah dengan infeksi. Untuk menguji metode yang diusulkan, dilakukan validasi unjuk kerja menggunakan K-NN dan 5-fold cross validation. Dari uji validasi ini, diperoleh akurasi deteksi tertinggi sebesar $90 \%$, dimana dicapai menggunakan 8 ciri dan metode Cosine K-NN. Metode yang diusulkan dapat mendeteksi LBP secara otomatis, ini mengungguli studi sebelumnya yang masih melakukan deteksi dan perhitungan secara manual. Studi lainnya menggunakan perangkat hematologi analyzer yang tentu saja sangat bergantung pada standar kerja produsen alat tersebut. Dengan usulan metode ini, diharapkan pada masa mendatang dapat menjadi pendukung pemeriksaan klinis dalam penegakan diagnosa DBD.

\section{DAFTAR RUJUKAN}

Arruan, R. D., Rambert, G., \& Manoppo, F. (2015). Limfosit Plasma Biru Dan Jumlah Leukosit Pada Pasien Anak Infeksi Virus Dengue Di Manado. Jurnal e-Biomedik, 3(1), 1-4. https://doi.org/10.35790/ebm.3.1.2015.7412

Aryu, C. (2010). Demam Berdarah Dengue: Epidemiologi, Patogenesis dan Faktor Risiko Penularan. Aspirator, 2(2), 119-120.

Clarice, C. S. H., Abeysuriya, V., de Mel, S., Thilakawardana, B. U., de Mel, P., de Mel, C., Chandrasena, L., Seneviratne, S. L., Yip, C., \& Yap, E. S. (2019). Atypical lymphocyte count correlates with the severity of dengue infection. PLOS ONE, 14(5), 1-11. https://doi.org/10.1371/journal.pone.0215061

Geler, Z., Kurbalija, V., Radovanović, M., \& Ivanović, M. (2016). Comparison of different weighting schemes for the kNN classifier on time-series data. Knowledge and Information Systems, 48(2), 331-378. https://doi.org/10.1007/s10115-015-0881-0 
Hasan S, Jamdar SF, Alalowi M, \& Al Ageel Al Beaiji SM. (2016). Dengue virus: A global human threat: Review of literature. J. Int Soc Prevent Communit Dent., 6, 1-6.

Ibrahim, N., Bacheramsyah, T. F., Hidayat, B., \& Darana, S. (2018). Pengklasifikasian Grade Telur Ayam Negeri menggunakan Klasifikasi K-Nearest Neighbor berbasis Android. ELKOMIKA: Jurnal Teknik Energi Elektrik, Teknik Telekomunikasi, \& Teknik Elektronika, 6(2), 288. https://doi.org/10.26760/elkomika.v6i2.288

Indrawan, M. A., Muhyi, A., \& Leatemia, L. D. (2018). Gambaran Hasil Pemeriksaan Serologis IgM dan IgG Dengue Pada Anak Penderita Demam Berdarah Dengue Berdasarkan Lama Hari Demam di RSUD Abdul Wahab Sjahranie Samarinda. Jurnal kedokteran Mulawarman, 5(2), 23-31.

Irianti, D. M., Reniarti, L., \& MS, A. (2016). Hubungan Jumlah Limfosit Plasma Biru dengan Spektrum Klinis dan Perannya dalam Memprediksi Perubahan Spektrum Klinis Infeksi $\begin{array}{lllll}\text { Dengue pada Anak. Sari Pediatri, } 325 . & \end{array}$ https://doi.org/10.14238/sp10.5.2009.325-30

Johnson, J. M., \& Yadav, A. (2018). Fault Detection and Classification Technique for HVDC Transmission Lines Using KNN. Dalam Information and Communication Technology for Sustainable Development (Nomor August, hlm. 245-253). https://doi.org/10.1007/978-981-10-3920-1_25

Kartika, J. I., \& Santoso, E. (2017). Penentuan Siswa Berprestasi Menggunakan Metode KNearest Neighbor dan Weighted Product (Studi Kasus: SMP Negeri 3 Mejayan). Jurnal Pengembangan Teknologi Informasi dan IImu Komputer, 1(5), 9.

Kemenkes RI. (2010). Demam Berdarah Dengue. Buletin Jendela Epidemiologi, 2, 48.

Khetarpal, N., \& Khanna, I. (2016). Dengue Fever: Causes, Complications, and Vaccine Strategies. Journal of Immunology Research, 2016(3). https://doi.org/10.1155/2016/6803098

Krisandi, N., \& Prihandono, B. (2013). Algoritma K-Nearest Neighbor Dalam Klasifikasi Data Hasil Produksi Kelapa Sawit Pada PT. Minamas Kecamatan Parindu. Buletin Ilmiah Math. Stat. dan Terapannya (Bimaster), 2(1), 6.

Kurane, I. (2007). Dengue hemorrhagic fever with special emphasis on immunopathogenesis. Comparative Immunology, Microbiology and Infectious Diseases, 30(5-6), 329-340. https://doi.org/10.1016/j.cimid.2007.05.010

Kusban, M. (2015). Verifikasi dan Identifikasi Telapak Tangan dengan Kernel Gabor. Jurnal Nasional Teknik Elektro dan Teknologi Informasi (JNTETI), 4(2). https://doi.org/10.22146/jnteti.v4i2.151 
Metrikawati, S. F. (2014). Model Dan Simulasi Transmisi Virus Dengue Di Dalam Tubuh Manusia. Jurnal Konvergensi, 4(2), 115-127.

Mustakimah, S. (2012). Gambaran Limfosit Plasma Biru (LPB) Berdasarkan Derajat Penyakit Pada Dengue Hemorrhagic Fever (DHF). Laporan Tugas Akhir. Universitas Muhamadiyah Semarang.

Naik, S., \& Koley, E. (2019). Fault Detection and Classification scheme using KNN for AC/HVDC Transmission Lines. International Conference on Communication and Electronics Systems (ICCES). https://doi.org/10.1109/ICCES45898.2019.9002230

Prabhavathi, Madhusudan, Suman, Govindaraj, \& Puttaswamy. (2017). Study of clinical and laboratory predictive markers of dengue fever and severe dengue in children. $J$ PediatrRes., 4(06), 397-404. https://doi.org/10.1037/0022-3514.51.6.1173

Raharjo, B., \& Hadi, S. (2019). High Fluorescent Lymphocyte Count Examination in Dengue Hemorrhagic Patients With Sysmex Xn-1000 Hematology Analyzer. Indonesian Journal of Clinical Pathology and Medical Laboratory, 25(2), 207. https://doi.org/10.24293/ijcpml.v25i2.1443

Sooai, A. G., Rumaksari, Atyanta. N., Khamid, K., Fanani, N. Z., Sumpeno, S., \& Purnomo, M. H. (2018). Deteksi Gestur Lengan Dinamis pada Lingkungan Virtual Tiga Dimensi Koleksi Warisan Budaya. Jurnal Nasional Teknik Elektro dan Teknologi Informasi (JNTETI), Л4). https://doi.org/10.22146/jnteti.v7i4.457

Sooai, A. G., Yoshimoto, K., Takahashi, H., Sumpeno, S., \& Purnomo, M. H. (2018). Dynamic Hand Gesture Recognition on 3D Virtual Cultural Heritage Ancient Collection Objects Using k-Nearest Neighbor. 8.

Sorisi, A. M. H. (2013). Transmisi Transovarial Virus Dengue Pada Nyamukaedes Spp. Jurnal Biomedik (Jbm), 5(1). https://doi.org/10.35790/jbm.5.1.2013.2042

Vitola, J., Pozo, F., Tibaduiza, D., \& Anaya, M. (2017). A Sensor Data Fusion System Based on k-Nearest Neighbor Pattern Classification for Structural Health Monitoring Applications. Sensors, 172), 417. https://doi.org/10.3390/s17020417

Wang, Y., Song, Q., Zhang, H., Huang, X., \& Zhou, Z. (2012). A new approach for landmine discrimination in SAR images. International Conference on Image Analysis and Signal Processing. https://doi.org/10.1109/IASP.2012.6425019 